\title{
Perspective: improving vitamin D status in the management of COVID-19
}

\author{
Maryam Ebadi ${ }^{1}$ Aldo J. Montano-Loza ${ }^{1}$
}

Received: 9 April 2020 / Revised: 28 April 2020 / Accepted: 1 May 2020 / Published online: 12 May 2020

(c) Springer Nature Limited 2020

\section{Introduction}

A novel coronavirus disease 2019 (COVID-19) outbreak is a global dramatic pandemic that is immeasurably impacting our communities. Considering massive health and economic burden of the COVID-19 pandemic, any means by which to improve the condition of patients to accelerate recovery and to reduce the risk of deterioration and death would be considered of significant clinical and economical importance.

In patients with COVID-19, SARS-CoV-2 virus binds to angiotensin converting enzyme 2 (ACE2) receptors in the respiratory tracts of infected patients to enter host cells [1]. At early stages of the disease, protective immune response is responsible for eliminating virus and, therefore, strategies to improve immune responses are of importance. As disease progresses, lung inflammation and fibrosis occur due to the release of pro-inflammatory cytokines, namely interleukin (IL)-1B and IL-18 by activated macrophages and type $1 \mathrm{~T}$ helper (Th1) immune cells [2]. Older patients and those that are immunocompromised are at the higher substantial risk [3]. Unfortunately, current knowledge gap on human immune response to SARS-CoV-2 is a critical barrier for treating the disease; however, potential immunomodulators may help alleviate severity and improve outcomes.

Vitamin D is a secosteroid that has a wide spectrum of immunomodulatory, antiinflammatory antifibrotic, and antioxidant actions. Expression of inflammatory cytokine [e.g., IL-1 $\alpha$, IL-1 $\beta$, tumor necrosis factor- $\alpha$ ] was inhibited by vitamin D and its insufficiency was associated with overexpression of Th1 cytokines [4]. We have recently found that severe vitamin $\mathrm{D}$ deficiency $(<25 \mathrm{nmol} / \mathrm{L})$ is associated

Aldo J. Montano-Loza

montanol@ualberta.ca

1 Division of Gastroenterology \& Liver Unit, University of Alberta Hospital, Edmonton, AB, Canada with disease progression and increased mortality in patients with autoimmune liver diseases [5]. This attribute has generated interest in vitamin $\mathrm{D}$ as a pathogenic factor that can be measured, monitored, and manipulated [6].

\section{Vitamin D deficiency in COVID-19 high risk patients}

Patients with common variable immunodeficiency and bronchiectasis [7] as well as older adults [8] who are detected with mild to severe vitamin D deficiency, constitute high risk groups for getting severe illness from COVID-19. In addition, vitamin D has an important role in cardiovascular diseases and diabetes mellitus [9]. Vitamin D deficiency is also common in obesity [10] and smokers [11]. In Chicago, more than half of COVID-19 cases and around $70 \%$ of COVID-19 deaths were observed in AfricanAmerican individuals [12] who are at the greater risk for vitamin D deficiency [13].

Among environmental factors, seasonal variation in sun exposure, geographic latitudes, air pollution, and darker skin influence in vitro vitamin D formation by sunlight [14]. Recent investigation of an association between temperature and latitude in the cities affected with COVID-19 indicated similarity in temperature and latitude among those highly affected areas [15]. This is an important notion that must be considered as vitamin $\mathrm{D}$ concentrations tended to be lower in high-latitude countries [16]. High prevalence of vitamin $\mathrm{D}$ deficiency and insufficiency was reported previously for those affected areas (Table 1); however, it should be acknowledged that divergent included populations may limit the generalizability of the study to other populations. Moreover, prevalence of vitamin D deficiency differs among various geographical regions of each country, which limit our ability to simplify the results.

\section{Vitamin D and respiratory tract infections}

Epidemiological studies have reported that vitamin D deficiency is associated with viral respiratory tract infections 
Table 1 Overview of vitamin D deficiency in regions highly affected by COVID-19.

\begin{tabular}{|c|c|c|c|}
\hline Country & Population of study & $25(\mathrm{OH}) \mathrm{D}$ status & Prevalence \\
\hline China [30] & 364 Chinese men aged $60-75$ & $\begin{array}{l}\text { Deficiency: }<50 \mathrm{nmol} / \mathrm{L} \\
\text { Insufficiency: } 50-75 \mathrm{nmol} / \mathrm{L}\end{array}$ & $\begin{array}{l}72 \% \\
22 \%\end{array}$ \\
\hline Iran [31] & $\begin{array}{l}\text { Meta-analysis of } 48 \text { studies including } 1911 \text { men and } 3683 \text { women (excluding } \\
\text { pregnant women, children, and patients) }\end{array}$ & Deficiency: $<50 \mathrm{nmol} / \mathrm{L}$ & $\begin{array}{l}\text { Pooled prevalence } \\
55.21 \% \text { in men } \\
64.71 \text { in women }\end{array}$ \\
\hline Italy and Spain [32] & 420 patients $\geq 65$ years old admitted to rehabilitation centers & $\begin{array}{l}\text { Deficiency: }<50 \mathrm{nmol} / \mathrm{L} \\
\text { Insufficiency: } 50-75 \mathrm{nmol} / \mathrm{L}\end{array}$ & $\begin{array}{l}94.3 \% \\
81.2 \%\end{array}$ \\
\hline United States [33] & 26010 adults in the National Health and Nutrition Examination Survey 2001-2010 & $\begin{array}{l}\text { Deficiency: }<50 \mathrm{nmol} / \mathrm{L} \\
\text { Insufficiency: } 50-75 \mathrm{nmol} / \mathrm{L}\end{array}$ & $\begin{array}{l}28.9 \% \\
41.4 \%\end{array}$ \\
\hline France [34] & 297 subjects studied in January and February 2015 & Deficiency: $<50 \mathrm{nmol} / \mathrm{L}$ & $75.1 \%$ \\
\hline United Kingdom [35] & $\begin{array}{l}278 \text { patients with chronic obstructive pulmonary disease, aged } 41-92 \text { years } \\
\text { in London }\end{array}$ & Deficiency: $<50 \mathrm{nmol} / \mathrm{L}$ & $61.5 \%$ \\
\hline
\end{tabular}

and acute lung injury [17]. Vitamin D agonist, calcitriol, exhibited protective effects against acute lung injury by modulating the expression of members of the renin-angiotensin system such as ACE2 in lung tissue [18], supporting the role of vitamin D deficiency as a pathogenic factor in COVID-19.

Vitamin D receptors (VDRs) are extensively distributed in respiratory epithelial cells and immune cells (B cell, T cell, macrophages, and monocytes). 25-hydroxyvitamin D (25OHD), the major circulating form of vitamin $\mathrm{D}$ can be converted to the active form (1,25-dihydroxyvitamin D) in the bronchial epithelium and immune cells [19]. The enzyme, $1 \alpha$-Hydroxylase (CYP27B1), required for vitamin $\mathrm{D}$ activation, is induced by diverse stimuli, including cytokines and toll-like receptor ligands in the respiratory tract. However, adequate serum levels of $25(\mathrm{OH}) \mathrm{D}$ is required to increase levels of 1,25-dihydroxyvitamin $\mathrm{D}$ and consequently improve the immune response to respiratory virus infections [20].

Type-II pneumocytes are the primary target of coronaviruses and ACE2 receptors are highly expressed on these cells. Impaired function of type-II pneumocytes decrease the surfactant level and increase surface tension in COVID-19 [21]. Metabolites of 1,25-dihydroxyvitamin D have been reported to stimulate surfactant synthesis in alveolar type-II cells [22]. In vitro culture of human fetal and adult alveolar type-II cells with 1,25-dihydroxyvitamin $D$ increased VDR and the expression of surfactantassociated protein $\mathrm{B}$, a lipid-associated protein of the pulmonary surfactant [23], indicating the potential of vitamin $\mathrm{D}$ to reduce surface tension in COVID-19.

In line with our objective to improve vitamin D status and its associated outcomes in patients with COVID-19, studies have shown treatment with high dose of 250,000-500,000 IU vitamin D to be safe in mechanically ventilated, critically ill patients and was associated with decreased hospital length of stay, improved ability of the blood to carry oxygen and increased hemoglobin levels $[24,25]$. The risk of acute viral respiratory tract infections was twofold less if the vitamin $\mathrm{D}$ serum levels were $\geq 95 \mathrm{nmol} / \mathrm{L}$ (hazard ratio $0.51 ; 95 \% \mathrm{CI}, 0.25-0.84 ; p<$ $0.0001)$ and the percentage of sick days was five times less $(0.80 \%$ vs. $3.9 \%, p=0.02)$ compared with the patients with levels $<95 \mathrm{nmol} / \mathrm{L}$ [26].

\section{Suggested plan of action}

To our knowledge, no study to date has measured vitamin D levels and performed high-dose vitamin D treatment in patients with COVID-19. High prevalence of vitamin D deficiency in elderly, smokers, patients with chronic diseases, and excess uptake by adipose tissue in obesity make investigations of its role as a therapeutic agent in COVID19 conceivable. Accordingly, it should be necessary to measure serum $25(\mathrm{OH}) \mathrm{D}$ levels in all inpatient and outpatient populations with COVID-19 and in different stages of the disease to identify the importance of maintaining or promptly increasing circulating levels of $25(\mathrm{OH}) \mathrm{D}$ into the optimal range of $40-60 \mathrm{ng} / \mathrm{ml}(100-150 \mathrm{nmol} / \mathrm{L})$ [27]. In this regard, relationship between baseline vitamin D status and disease severity, laboratory biochemical tests of white blood cell count, C-reactive protein, lymphocyte count, lactate dehydrogenase, IL-6, platelet count, albumin, and serum ferritin, required hospitalization and intensive care unit admission should be determined. This will help us to identify the ability of low vitamin D levels to risk stratify patients and allow for care to be provided to those who are at increased risk of progression.

We acknowledge that the primary stage in treating vitamin $\mathrm{D}$ deficiency is to measure a baseline $25(\mathrm{OH}) \mathrm{D}$ serum levels and then consider the supplementation dose based on the target level and how rapidly that level must be reached. However, based on previous studies in patients with reparatory disease [28] and in order to quickly and safely increase serum $25(\mathrm{OH}) \mathrm{D}$ levels, we recommend patients with low circulating levels (below $50 \mathrm{nmol} / \mathrm{L}$ ) should be offered vitamin D supplementation of 50,000 IU twice a week at the diagnosis (100,000 IU total). Overall, doses 
above $6000 \mathrm{IU} / \mathrm{d}$ are needed to achieve serum 25(OH)D concentrations above $100 \mathrm{nmol} / \mathrm{L}$ and intakes of vitamin D up to $15,000 \mathrm{IU} / \mathrm{d}$ were found to be safe [29]. Association between patients' initial response to vitamin D supplementation with disease progression, recovery, and various clinical outcomes need to be investigated. Following $100,000 \mathrm{IU}$ start dose, we propose patients to continue with the dose of 50,000 IU taken once a week for the second and third weeks. Following doses of 50,000 IU is suggested to achieve optimal levels of $25(\mathrm{OH}) \mathrm{D}$ in patients with poor baseline vitamin D status. Supplemented patients should be monitored to ensure their circulating vitamin levels are normalized and sustained for the duration of the COVID-19 pandemic. This suggested plan presents important challenges to identify how disease features and progression, hospital admission and length of stay, duration of mechanical ventilation, hospital mortality, and respiratory failure differ between the early responder and nonresponder groups.

\section{Conclusion}

Due to the lack of data, symptomatic management is used for COVID-19 infection including oxygen therapy and mechanical ventilation for those with severe infection. Considering the range of beneficial effects ascribed to vitamin $\mathrm{D}$, it is safety and ease of administration, as well as direct effects of vitamin D on immune cell proliferation and activity, pulmonary ACE2 expression and reducing surface tension, evaluation of vitamin D supplementation as an adjuvant therapeutic intervention could be of substantial clinical and economic significance. Empiric intervention with vitamin $\mathrm{D}$ is a clinical decision that can be justified by low serum levels and the risk of impaired immune system. Importantly, improvement in circulating $25(\mathrm{OH}) \mathrm{D}$ levels opens possibilities for slowing disease progression or even improving survival of patients.

In summary, given the high prevalence of vitamin D deficiency and in order to rapidly, safely, and significantly raise serum concentrations, high-dose vitamin D intervention with potential benefit in decreasing risk of COVID-19 severity and mortality is suggested, which is a safe and noninvasive treatment. Patients would take large doses of vitamin D for a week, followed by several thousand IU/d vitamin D for a period of 2 weeks. This will provide a quick and sustainable restoration of serum vitamin D levels, thus, potentially triggering an improvement in clinical status and prognosis. However, prospective clinical studies are required to address this speculation and overcome the obstacles in our current understanding of vitamin D role as an adjuvant therapy in patients with COVID-19.

\section{Compliance with ethical standards}

Conflict of interest The authors declare that they have no conflict of interest.

Publisher's note Springer Nature remains neutral with regard to jurisdictional claims in published maps and institutional affiliations.

\section{References}

1. Hoffmann M, Kleine-Weber H, Schroeder S, Kruger N, Herrler T, Erichsen S, et al. SARS-CoV-2 Cell entry depends on ACE2 and TMPRSS 2 and is blocked by a clinically proven protease inhibitor. Cell. 2020. https://doi.org/10.1016/j.cell.2020.02.052.

2. Conti P, Ronconi G, Caraffa A, Gallenga CE, Ross R, Frydas I, et al. Induction of pro-inflammatory cytokines (IL-1 and IL-6) and lung inflammation by Coronavirus-19 (COVI-19 or SARS-CoV2): anti-inflammatory strategies. J Biol Regul Homeost Agents. 2020;34. https://doi.org/10.23812/CONTI-E.

3. Cascella M, Rajnik M, Cuomo A, Dulebohn SC, Di Napoli R. Features, evaluation and treatment coronavirus (COVID-19). Treasure Island, FL: StatPearls; 2020.

4. Hughes DA, Norton R. Vitamin D and respiratory health. Clin Exp Immunol. 2009;158:20-5. https://doi.org/10.1111/j.13652249.2009.04001.x.

5. Ebadi M, Bhanji RA, Mazurak VC, Lytvyak E, Mason A, Czaja $\mathrm{AJ}$, et al. Severe vitamin $\mathrm{D}$ deficiency is a prognostic biomarker in autoimmune hepatitis. Aliment Pharmacol Ther. 2019;49:173-82.

6. Czaja AJ, Montano-Loza AJ. Evolving role of vitamin D in immune-mediated disease and its implications in autoimmune hepatitis. Dig Dis Sci. 2019;64:324-44.

7. Amaya-Mejia AS, O'Farrill-Romanillos PM, Galindo-Pacheco LV, Vargas-Ortega G, Mendoza-Zubieta V, Del RiveroHernandez LG, et al. Vitamin D deficiency in patients with common variable immunodeficiency, with autoimmune diseases and bronchiectasis. Rev Alerg Mex. 2013;60:110-6.

8. Meehan M, Penckofer S. The role of vitamin D in the aging adult. J Aging Gerontol. 2014;2:60-71.

9. Peterlik M, Cross HS. Vitamin D and calcium deficits predispose for multiple chronic diseases. Eur J Clin Invest. 2005;35:290-304.

10. Dhaliwal R, Mikhail M, Feuerman M, Aloia JF. The vitamin D dose response in obesity. Endocr Pract. 2014;20:1258-64.

11. Kassi EN, Stavropoulos S, Kokkoris P, Galanos A, Moutsatsou P, Dimas C, et al. Smoking is a significant determinant of low serum vitamin $\mathrm{D}$ in young and middle-aged healthy males. Hormones. 2015;14:245-50.

12. Yancy CW. COVID-19 and African Americans. JAMA. 2020. https://doi.org/10.1001/jama.2020.6548.

13. Alzaman NS, Dawson-Hughes B, Nelson J, D'Alessio D, Pittas AG. Vitamin D status of black and white Americans and changes in vitamin D metabolites after varied doses of vitamin D supplementation. Am J Clin Nutr. 2016;104:205-14.

14. Wacker M, Holick MF. Sunlight and vitamin D: a global perspective for health. Dermatoendocrinol. 2013;5:51-108.

15. Sajadi MM, Habibzadeh P, Vintzileos A, Shokouhi S, MirallesWilhelm F, Amoroso A. Temperature, humidity and latitude analysis to predict potential spread and seasonality for COVID-19. SSRN. 2020. https://doi.org/10.2139/ssrn.3550308.

16. Cannell JJ, Vieth R, Umhau JC, Holick MF, Grant WB, Madronich $\mathrm{S}$, et al. Epidemic influenza and vitamin D. Epidemiol Infect. 2006;134:1129-40.

17. Hansdottir S, Monick MM. Vitamin D effects on lung immunity and respiratory diseases. Vitam Horm. 2011;86:217-37. 
18. Xu J, Yang J, Chen J, Luo Q, Zhang Q, Zhang H. Vitamin D alleviates lipopolysaccharideinduced acute lung injury via regulation of the reninangiotensin system. Mol Med Rep. 2017;16:7432-8.

19. Pfeffer PE, Hawrylowicz CM. Vitamin D and lung disease. Thorax. 2012;67:1018-20.

20. Greiller CL, Martineau AR. Modulation of the immune response to respiratory viruses by vitamin D. Nutrients. 2015;7:4240-70.

21. Bombardini T, Picano E. Angiotensin converting enzyme 2 as the molecular bridge between epidemiologic and clinical features of COVID-19. Can J Cardiol. 2020. https://doi.org/10.1016/j.cjca. 2020.03.026.

22. Rehan VK, Torday JS, Peleg S, Gennaro L, Vouros P, Padbury J, et al. 1Alpha,25-dihydroxy-3-epi-vitamin D3, a natural metabolite of 1alpha,25-dihydroxy vitamin D3: production and biological activity studies in pulmonary alveolar type II cells. Mol Genet Metab. 2002;76:46-56.

23. Phokela SS, Peleg S, Moya FR, Alcorn JL. Regulation of human pulmonary surfactant protein gene expression by 1alpha,25dihydroxyvitamin D3. Am J Physiol Lung Cell Mol Physiol. 2005;289:617-26.

24. Han JE, Jones JL, Tangpricha V, Brown MA, Brown LAS, Hao L, et al. High dose vitamin D administration in ventilated intensive care unit patients: a pilot double blind randomized controlled Trial. J Clin Transl Endocrinol. 2016;4:59-65.

25. Smith EM, Jones JL, Han JE, Alvarez JA, Sloan JH, Konrad RJ, et al. High-dose vitamin D3 administration is associated with increases in hemoglobin concentrations in mechanically ventilated critically Ill adults: a pilot double-blind, randomized, placebo-controlled trial. JPEN J Parenter Enter Nutr. 2018; 42:87-94.

26. Sabetta JR, DePetrillo P, Cipriani RJ, Smardin J, Burns LA, Landry ML. Serum 25-hydroxyvitamin D and the incidence of acute viral respiratory tract infections in healthy adults. PLoS ONE. 2010;5:e11088.
27. Ekwaru JP, Zwicker JD, Holick MF, Giovannucci E, Veugelers PJ. The importance of body weight for the dose response relationship of oral vitamin D supplementation and serum 25-hydroxyvitamin D in healthy volunteers. PLoS ONE. 2014;9:e111265.

28. Martineau AR, Nanzer AM, Satkunam KR, Packe GE, Rainbow SJ, Maunsell ZJ, et al. Influence of a single oral dose of vitamin D (2) on serum 25-hydroxyvitamin D concentrations in tuberculosis patients. Int J Tuberc Lung Dis. 2009;13:119-25.

29. Kimball SM, Mirhosseini N, Holick MF. Evaluation of vitamin D3 intakes up to 15,000 international units/day and serum 25hydroxyvitamin D concentrations up to $300 \mathrm{nmol} / \mathrm{L}$ on calcium metabolism in a community setting. Dermatoendocrinol. 2017;9: e1300213.

30. Zhang W, Zheng X, Wang Y, Xiao H. Vitamin D deficiency as a potential marker of benign prostatic hyperplasia. Urology. 2016;97:212-8.

31. Tabrizi R, Moosazadeh M, Akbari M, Dabbaghmanesh MH, Mohamadkhani M, Asemi Z, et al. High prevalence of vitamin D deficiency among iranian population: a systematic review and meta-analysis. Iran J Med Sci. 2018;43:125-39.

32. Lelli D, Perez Bazan LM, Calle Egusquiza A, Onder G, Morandi A, Ortolani E, et al. $25(\mathrm{OH})$ vitamin $\mathrm{D}$ and functional outcomes in older adults admitted to rehabilitation units: the safari study. Osteoporos Int. 2019;30:887-95.

33. Liu X, Baylin A, Levy PD. Vitamin D deficiency and insufficiency among US adults: prevalence, predictors and clinical implications. Br J Nutr. 2018;119:928-36.

34. Deplanque X, Wullens A, Norberciak L. Prevalence and risk factors of vitamin D deficiency in healthy adults aged 18-65 years in northern France. Rev Med Interne. 2017;38:368-73.

35. Jolliffe DA, James WY, Hooper RL, Barnes NC, Greiller CL, Islam K, et al. Prevalence, determinants and clinical correlates of vitamin $\mathrm{D}$ deficiency in patients with chronic obstructive pulmonary disease in London, UK. J Steroid Biochem Mol Biol. 2018;175:138-45. 